\title{
Lis Højgaard
}

\section{At komme til magten \\ - magt, køn og kønnede aktører i det politiske felt}

Køn og politik spiller i dag sammen på mangfoldige måder. Alligevel er der tale om kønnede monstre $\mathrm{i}$ måden at agere på i det politiske felt. I artiklen analyseres interviews med danske toppolitikere, som viser, at kvindelige og mandlige politikere taler forskellige handle- og forhandlingsrum frem i den måde de kobler diskurser om at komme til magten og diskurser om kon på. 
$\mathrm{H}$ istorien om kønnet og politikken fortælles på mange måder som en marginaliseringshistorie (Haavio-Mannila 1983), et spørgsmål om repræsentation (Lovenduski \& Norris 1993; Raum 1995), med udgangspunkt i forskelle, der karakteriserer gruppen af hhv. mandlige og kvindelige politikere (Skjeie 1992, 1995; Eduards 1998) eller som en bevægelse fra det ufærdige demokrati til ligestillingsdemokratiet (Bergqvist 1999).

Intentionen her er at gå en anden vej, og fortælle historien om kønnet og politikken fra en vinkel, der tager udgangspunkt i det politiske felt og de politiske praksisser og strategiske positioneringer, der indgår i "at komme til magten" - i at blive toppolitikker - og som ser på samspillet mellem det politiske felt og forståelser af køn og kønnede positioner, dvs. på hvilke måder, ved hjælp af hvilke relationer, gennem hvilke alliancer og individuelle præstationer, det er muligt at komme til magten, og hvordan køn "tales" og "gøres" på måder, der fungerer støttende eller modarbejdende i forhold til disse bestræbelser (West \& Zimmerman 1987).

Analysen henter sin teoretiske forståelseshorisont i en opfattelse af, at både køn og magt er fænomener, der bestandigt skabes og opretholdes gennem diskursive praksisser ${ }^{1}$. Diskursive praksisser skal her forstås i Davies \& Harré's betydning, som de måder hvorpå mennesker aktivt producerer sociale og psykologiske realiteter ( Davies \& Harré 1990). Det er gennem de diskursive praksissers aktivering af tilgængelige diskurser - forstået som institutionaliseret brug af sprog og sproglignende tegnsystemer (Davies \& Harré 1990) - at de relationer, som udgør såvel kønnets som magtens mulighedsbetingelser, skabes (Gordon 1980:236). Det er diskurser og diskursive praksisser, som konstituerer og oprethol- der såvel magtens som kønnets mønstre. Diskurserne aftegner en række mulige positioner, som individerne kan gøre brug af $i$ en given sammenhæng (Heede 1992). De aktiveres gennem konkrete individers handlinger - og denne aktivering har en subjektiverende effekt på individerne i den forstand, at de på samme tid både er underkastet diskurserne, finder deres handlemuligheder gennem dem (Weedon 1987; Søndergaard 2000) og skaber subjektpositioner ud fra dem eksempelvis positioner som kønnede politiske aktører i en given historisk kontekst.

\section{Det politiske felt}

Det politiske felt rummer komplekse processer, der indebærer koblinger og medieringer mellem forskellige samfundsmæssige kræfter og individuelle måder at forholde sig på. Det er konstitueret gennem ordensskabende og meningsgivende diskurser, som genererer, opretholder og formidler, hvad man med et lån fra Foucault (1980) kunne kalde sandhedsregimer i det politiske felt. Disse diskurser aflæses, aktiveres og formes af konkrete individer i deres daglige politiske praksis og i den proces, der bringer politikerne til magten.

Jeg vil i det følgende give et indblik i den del af feltet, som åbnes gennem de historier, kvindelige og mandlige politikere fortæller om deres vej ind i og op gennem feltet til politiske toppositioner. Kompleksiteten og mangfoldigheden i det politiske felt afspejles konkret i, at der er mange veje til magten i politik. De tyve interviews ${ }^{2}$, der indgår i denne analyse, fortæller tyve forskellige historier om vejen til toppen i dansk politik. Alle historierne er stærke jeg-fortællinger - det er handlekraftige og viljestærke kvinder og mænd, der fortælles frem. Historierne viser, hvordan politikere håndterer feltets vilkår gennem deres måde at bruge og 
forme tilgængelige diskurser på, og hvordan de som kønnede aktører positionerer sig gennem koblinger af feltets diskurser.

Analysens udgangspunkt er tre knudepunkter i historierne - affødt af mine interviewspørgsmål. Det første handler om den politiske praksis - om hvordan man arbejder politisk. Det andet knudepunkt handler om at komme til magten det er beskrivelser af, hvordan politikerne er nået de positioner, de sidder på i dag, og det tredje handler om kønnets betydning i politik. Disse knudepunkter udtrykker en brug at feltets tilgængelige diskurser, som ofte går på tværs af parti, køn og generation, og som ofte rummer modsætninger inden for den enkelte politikers historie. Jeg har på baggrund af historierne indkredset tre sæt af diskurser: en praksisdiskurs, som samler de diskursive elementer i politikernes refleksioner over, hvordan det politiske arbejde foregår, hvem samarbejder man med, hvem former man alliancer med, hvordan tager man beslutninger, og hvad der er politiske succeser og hvad der karakteriserer den gode politiker. Denne diskurs får karakter af en metadiskurs. Den rummer normative elementer, der bringes frem i vurderinger af politikere og politiske handlemåder, som danner grundlag for inklusions- og eksklusionsprocesser i feltet. Det andet sæt af diskurser handler om at komme til magten og består af tre forskellige diskurser med hver sine karakteristiske træk. Jeg har givet dem navne efter det, der er i hvert enkelt tilfælde synes at være det enkelttræk, som mest markant adskiller dem fra de andre: 1. Kampen, 2. Partifællesskabet, 3. Den personlige indsats ${ }^{3}$. Elementerne i disse tre diskurser indgår i forskellig grad i hovedparten af interviewene og på tværs af partier - bortset fra diskursen om Partifællesskabet, som kun findes blandt socialdemokratiske politikere.

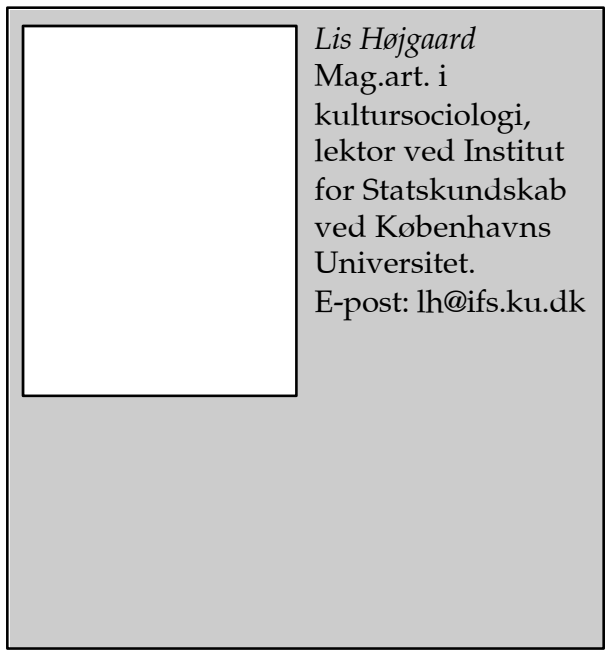

Jeg vil for nemheds skyld i det følgende kalde disse diskurser om at komme til magten for magtdiskurser ${ }^{4}$. Det tredje sæt af diskurser handler om forholdet mellem køn og politik og præsenteres i to diskurser: Én, der rummer en eksplicit italesættelse af køn som et betydningsfuldt element i relation til den politiske praksis, og en diskurs, der rummer en italesættelse af køn som betydningsløst i den politiske praksis. I det følgende præsenterer jeg de tre sæt diskurser og diskuterer praksisdiskursen - $\mathrm{i}$ dens egenskab af metadiskurs - i forhold til magtdiskurserne. Herefter bringer jeg de kønnede politiske aktører ind og viser, hvordan magtdiskurs og kønsdiskurs kobles af feltets kønnede aktører og diskuterer på denne baggrund samspillet mellem køn og politik.

\section{En praksisdiskurs}

Gennem praksisdiskursen udtrykkes normer for det politiske arbejde, for de måder hvorpå vilkår, muligheder og grænser i det politiske felt håndteres og bør håndteres. Disse måder kan siges at aktivere både et formelt og et uformelt regelsæt. Det formelle regelsæt sætter rammerne for samspillet mellem den enkelte politiker, gruppen, dvs. partifællerne i 
folketinget, kommunalbestyrelsen eller amtskommunalbestyrelsen, partiet i øvrigt samt politikerne fra de øvrige partier. Dette samspil er omdrejningspunktet i den politiske hverdag og udgør den politiske praksis' formelle bevægelsesrum, og her er det samarbejdet, der lægges vægt på. Samarbejdet modstilles politisk enegang, prioritering af enkeltsager og personlige politiske mål. De uformelle regler angiver, hvordan dette bevægelsesrum udformes. Det udtrykkes først og fremmest igennem, hvad der er god praksis. Det vigtigste er her - ud over de udstrakte krav til samarbejde - fortrolighed, tillid og loyalitet. Tillids- og fortrolighedsforskrifterne gælder både forholdet mellem politiker og politisk bagland og mellem politikere fra forskellige partier. I den sidste relation handler det især om at holde indgåede aftaler, at stå ved det, man er blevet enige om, være loyal over for fælles beslutninger. En anden vigtig del af forskrifterne for den gode politiske praksis er resultatorientering og konstruktivitet. Praksisdiskursen omfatter også en række personlige egenskaber, som tillægges særlig betydning. Det gælder først og fremmest stor arbejdsindsats, at kunne sit stof, flid og grundighed. Hertil lægges en række evner, som ikke kan tillæres og som ikke er enhver beskåret. Disse evner kan opveje mangler i personlige egenskaber eller manglende overholdelse af foreskrevne adfærdsregler. Det er politisk instinkt, politisk tæft, formidlingsevne.

Normerne, de personlige egenskaber og de særlige evner, som er angivet her, kan også beskrives ved deres modsætning og tilsammen danner de grundlag for inklusions- og eksklusionsprocesser, som de kommer til udtryk i praksisdiskursen:

Samarbejde - enkeltsager

Loyalitet - illoyalitet
Resultater - personlig markering

Konstruktivitet - destruktivitet

Flid - dovenskab

Politisk instinkt - formidling

Politisk tæft - mangel på samme

Disse modsætningspar bruges i forskellige kombinationer til karakteristik af personer og begivenheder, samarbejdsrelationer og præferencer. Ved hjælp af disse karakteristikker kan billedet af idealpolitikeren stykkes sammen, som den samarbejdende, vidende og hårdtarbejdende, loyale, resultatorienterede og konstruktive politiker, der har politisk instinkt og tæft. Men modsætningsparrene bringes også i spil på måder, som kompenserer for mangler på et felt ved at supplere med positive egenskaber på andre felter. Således kan andre respekterede politiske figurer eksempelvis være den dovne politiker, der har tæft eller viser loyalitet og samarbejdsvilje. Eller den politiker, der ikke evner at få resultater igennem, men som besidder blændende evner for at formidle det politiske budskab til omverdenen, og som derfor bliver en agtet medspiller i det politiske spil. Den politiker, der prioriterer personlig markering højt, synes at ligge langt nede i det interne vurderingshierarki, en position, der understreges og forstærkes af, at modstillingen til den personlige markering er resultatorientering. Der er ingen eksempler på, at en politiker karakteriseres som både resultatorienteret og som en person, der prioriterer personlig markering højt. Denne praksisdiskurs har således forskrifter både om den gode politiker og om den gode praksis, og den bruges - som jeg vil vise i det følgende - i karakteristikker af den politiske praksis og af politikere, ligesom diskursen kan bruges i tolkningen af den relative betydning af magtdiskurser og kønnede aktører. Men først til de tre magtdiskurser. 


\section{At komme til magten}

Den første diskurs om at komme til magten har jeg kaldt kampen. Det er en diskurs, der fremhæver modsætningen mellem fællesskabet og individet og mellem parti, partifæller og grupperinger af politikere og den enkelte politiker, det etablerede partiapparat over for de nyankomnes egen organisering. Men det handler også om kamp om værdier, om hierarkier og om fornyelse.

\section{Kampen}

At komme til magten er først og fremmest en kamp om positioner, alles kamp mod alle inden for partiet. Kampen starter før man bliver valgt og handler om placering på partilisten, dernæst handler den om vælgernes gunst og så fortsætter den efter man er blevet valgt:

...det har været en benhård kamp hele tiden, uafbrudt. Og du skulle være hurtig. Hvis kampen stod om at få en plads i et eller andet udvalg og skabe opbakning til at $d u$ skal have den plads, så skal du vide det, før pladsen bliver slået op, og du skal have skabt dit flertal, før den besættes. Og det er der jo også andre, der er i gang med. Altså konkrete kampe om ordførerskaber, det er som regel det, det handler om i Folketinget (kvindelig politiker).

Politik er en magtkamp og man skal bringe sig i position til at vinde kampen:

... så finder man nogle områder og siger her skal man have formuleret en politik, og så tager man førertrøjen på, selv om der er andre, der vil have den og selv om man ikke må for de gamle i gruppen, så gør man det bare alligevel.. (mandlig politiker).
... man kan lave alliancer, det er blandt andet det kaffeklubberne blev brugt til. De var alliancer og dermed også i forskellige situationer magtbaser, hvor man hjalp hinanden og hvor man lavede alliancer med andre (kvindelig politiker).

Man skal kæmpe for at holde positionen, og kampen gælder partifællerne:

...du skal jo flytte dem ved siden af dig, for hvis du ikke får flyttet dem, så er det dem, der făr den næste post - det er jo en intens magtkamp, det er der hver dag i gruppen, der er generalforsamling hver dag (...) hvis jeg ikke ved, hvad der foregår, så falder de mig i nakken - det gør de alligevel, men så har de grund til at falde mig i nakken - jeg er til gruppemøde hver eneste dag (kvindelig politiker).

Magtkampen er ikke bare en kamp mellem partifæller om positioner, men omfatter også ledelsens kamp for at forblive ledelse, en kamp der indebærer en afvejning og afbalancering af magtfulde grupperinger gennem tildeling af positioner. Ingen bliver ministre for deres blå øjnes skyld, som det udtrykkes. Våbenene i kampen er at skabe alliancer, være velinformeret og orienteret om hvad der foregår, være synlig for ledelsen, have politisk tæft og have magtbaser i og uden for parti og folketing, kommunalbestyrelse eller amtsråd. Kampen om positionerne betyder overvindelse af modstand og indebærer ofte en position som rebel, hvor man er i opposition, provokerer eller udfordrer. Der er ingen automatik i opstigningen gennem positioner; der skal kæmpes om hver en post. Dette billede bliver klarere gennem fremstillingen af, hvordan det politiske arbejde gribes an 
og hvilke samarbejdsrelationer, der prioriteres:

Som politiker herinde kører du jo solohistorierne, altså selvfølgelig er du sammen med en folketingsgruppe og du skal have dem til at være med på ideerne (...) På den ene side kører du alene, fordi det er dine sager, og dem vil du gerne køre, og andre skal ikke komme og tage dem og profilere sig på dem. Så der kører du nogle sager, og du har nogle netværk kørende rundt om dig og bag ved dig. $\mathrm{Og}$ så skal du have det placeret her (herinde), så det vil sige, du skal også kunne fungere i en gruppe herinde (kvindelig politiker).

Først og fremmest skal du have en vilje til at gennemføre det, du selv mener. Du skal nok være rimeligt stålsat og sikker på at det, du selv mener, det er det, der er det rigtige. Men samtidig skal du have en meget stor forståelse for, at folk man forhandler med også skal have noget, der er ingen, der skal tabe ansigt, det tror jeg er vigtigt (mandlig politiker).

Dette står ikke i modsætning til også at inddrage andre i overvejelser over, hvordan man skal gå til værks. Man søger at finde sympatisører for sine ideer, få opbakning i sin partiorganisation og skabe sig alliancer, også uden for politik. Et af redskaberne til at få sine ideer igennem er eksempelvis etablering af mere permanente netværk eller faste grupper, der mødes over længere tid, som både kan være ekspertnetværk, sat sammen fra sag til sag, løbende personlige netværk eller deltagelse i eksisterende grupper i samfundet:
(...) Så prøver jeg det af i forskellige NGO-grupper, som jeg prøver at alliere mig med og færdes i, det er der hvor fornyelserne meget ofte sker, i hvert fald i det danske samfund. De sker jo ikke i de store etablerede systemer... (kvindelig politiker).

\section{(...) jeg har lavet kredse omkring mig, hvor jeg har diskuteret med folk, som jeg i og for sig har udpe- get. Ikke nødvendigvis og måske i virkeligheden aldrig efter kriterier på, om folk var partimedlemmer, men på kriterier om folk havde no- get at sige og havde lyst til at gå ind i det (...) (kvindelig politiker).}

Disse historier om at komme til magten viser, hvordan nogle politikere læser den politiske praksis, hvordan de orienterer sig i forhold til den og bevæger sig inden for den. Herigennem bliver de også medkonstituerende af den. Disse politikere aflæser og skaber en politisk "virkelighed" gennem deres diskursive praksis, som har den ensomme forkæmper som sit omdrejningspunkt, der kæmper for egne politiske mærkesager, som markerer sig strategisk, går efter klart definerede mål og positioner, ofte med partiorganisationen og dele af partiet som modstandere, og hvis alliancepartnere dels er vælgerne - for mange er der tale om at sprænge partilisten ved valg og om høje stemmetal - dels er folk i samme situation, for det meste jævnaldrende og ligesindede. Den "ensomme forkæmper" henter politisk inspiration i bredere politiske strømninger og i samfundsdebatten frem for i den interne partidiskussion.

\section{Partifallesskabet}

En anden diskurs om at komme til magten handler om deltagelse i fællesskabet, 
om at vokse op igennem et politisk og socialt fællesskab, om hvordan den enkelte politiker skabes gennem fællesskabet:

...ungdomspolitik var jo på det niveau (arbejdet i en amtskommunal politisk ungdomsorganisation) et fantastisk liv, vi fik jo et fællesskab, og man fik en rolle, og man fik et selvværd igennem det fællesskab (mandlig politiker).

Jeg kan huske det ret tidligt med kammeraterne i ungdomsorganisationen, altså det var ikke kun det at være med til at bestemme, det var også det at være med i sig selv (kvindelig politiker).

Et fællesskab, hvor de ældre og mere erfarne sørger for de yngre gennem opfordringer f.eks. til at opstille til poster, til at deltage i grupper, til at skrive politiske oplæg, gennem opmuntring eller ved at inddrage de yngre $\mathrm{i}$ arbejdet. $\mathrm{Og}$ hvor de unge viser mentorerne respekt, loyalitet og taknemmelighed, ja, stadig omtaler dem med ærbødighed, nu hvor de selv sidder i toppositioner. Rekrutteringen foregår via talentspejdere, gennem uformelle kanaler, familie, venner, samarbejdsrelationer, organisatoriske og arbejdsmæssige kontakter og den politiske organisations mange led og forgreninger. At komme i betragtning her handler om at være initiativrig, handlekraftig, politisk kreativ, dygtig og solid - man skal vise, at man kan, man skal fortjene tilliden og kunne leve op til forventningerne. At blive indlemmet i fællesskabet betyder, at man får chancerne, at muligheder er åbne, at man så at sige befinder sig der, hvor positionerne lander. Eller som politikerne selv formulerer det:

Intervieweren: Når du fortæller historien, så lyder det ikke som om du har skulle kæmpe så meget om de poster du har haft?

Den interviewede: Nej, egentlig ikke. Det sjove er, at det er gået helt naturligt... (mandlig politiker).

Altså min placering og min force har i hele forløbet (...) været, at jeg på en eller anden måde er kommet ind i kernehuset, hvor der blev skrevet og formuleret, og har været med til at sætte dagsordenen (mandlig politiker).

Det betyder ikke, at der ikke er konkurrence, snarere, at den ikke forstås som magtkamp, men i højere grad som et vilkår. Konkurrencen går ikke mellem partierne, men inden for partierne, fordi den politiske karriere skal skabes inden for eget parti - man er både konkurrenter og kolleger. I diskursen indgår også en italesættelse af politikeren, som en del af et kollegialt fællesskab, hvor man nok tager udgangspunkt i egne oplevelser og ideer, men tillægger dialogen, kompromiser i forhold til partiets holdninger og fælles indsats stor vægt. Samarbejdet foregår inden for det politiske felt og eksterne kontakter nævnes stort set ikke, de synes ikke at have nogen betydning for det daglige politiske arbejde, ligesom opbygningen af eksterne netværk ikke har plads i denne diskurs i modsætning til kampdiskursen.

De politikere, der har gjort denne diskurs til deres egen, fortæller typisk en historie om en karriere- og udviklingsvej, hvor den vordende toppolitiker starter $\mathrm{i}$ partiets ungdomsorganisation, som medlem eller eventuel stifter af en ny afdeling, senere som formand eller kasserer, evt. amtsformand eller i landsledelsen, så medlem af bestyrelsen i partiforeningen, så inddraget i politikformuleren- 
de udvalg i partiregi, opstillet til kommunalbestyrelse og/eller folketing, medlem af vigtige udvalg, ordfører og udvalgsformand etc. Historien, der fortælles gennem denne diskurs, fremhæver en naturlig fremadskridende proces inden for et fællesskab, der har brug for dig, hvis forventninger du indfrier og vokser med, men sjældent vokser fra, og hvor fællesskabet honoreres gennem åben anerkendelse og ofte taknemmelighed over for dem, der hjalp på vejen. Det er en kollektiv fortælling om personlig og politisk loyalitet mellem generationer, hvor den politiske loyalitet - $\mathrm{i}$ betydningen tradition - også ind imellem brydes med politisk nytænkning.

\section{Den personlige indsats}

En tredje diskurs om at komme til magten formulerer den personlige indsats som det afgørende element. Den giver forrang til politikeren som person i harmonisk samspil med kolleger og parti. Relationen mellem den enkelte politiker og partiet er sjældent modsætningsfyldt, den er et spørgsmål om forhandling. Partiet synes i denne diskurs at være en organisation, ikke et fællesskab. Diskursen handler om valg og vilje, om lyst og evner, om personlige beslutninger og beslutsomhed, om at sætte sin vilje igennem og nå de resultater man går efter, og om at satse og om at have ambitioner om at gøre en forskel.

Så besluttede jeg mig simpelthen for (...) at jeg godt ville prøve at komme i Folketinget, men det skulle være på en meget sikker plads. Det var en meget privat beslutning (...) Det gjorde jeg på den måde, at jeg sagde, når jeg får et tilbud, der er så godt, at jeg kan se, at her er der bingo, så springer jeg til (kvindelig politiker).
Det er fordi, jeg ikke er bange for at sige ja eller nej, når der er brug for det, og fordi jeg mener uden blusel, at det gør en forskel, om det er mig eller en anden. Det er de to forhold, som jeg mener er årsagen til, at jeg sidder her (kvindelig politiker).

Arbejdsindsatsen og den personlige arbejdsevne er afgørende:
Altså Folketinget er en arbejds- plads, hvor indflydelsen i høj grad følger indsatsen, altså det gælder mange arbejdspladser, men det er i Folketinget meget udpræget, at indflydelsen er stærkt afhængig af det engagement og den arbejds- indsats og den evne til at løse pro- blemer, som den enkelte har. Der er en bestandig prøvelse, og de, der har viljen og evnen til at gøre et solidt stykke politisk arbejde, vurderes positivt af deres kolleger (mandlig politiker).

Men det handler også om personligt at kunne stå inde for det, man er med til at beslutte. Man kan som politiker komme i situationer, hvor man som person må afveje, hvad man kan være med til og hvad man ikke kan være med til. Selv om man er valgt til parlamentet og selv om man skal arbejde for partiets politik, kan der opstå tilfælde hvor den enkeltes personlige grænser er snævrere end partiets. Selv om det politiske arbejde opfattes som holdarbejde, er den personlige indsats og personlige vurdering afgørende. Samarbejdet omfatter også i denne diskurs netværk, men her er der tale om netværk, der består af - ikke relativt faste grupper, der mødes over en årrække - men enkeltpersoner, organisationer eller virksomheder, som man kontakter, når man af forskellige grunde har brug for det - som 
inspiration og indhentning af viden.

Politikergerningen, som den fortælles frem i denne diskurs, kommer til at ligne et almindeligt job, hvor sager skal håndteres, opgaver udføres og problemerne skal løses, når de opstår. Den diskursive praksis omfatter her at ordne, rette op på skævheder og skabe konkrete resultater og de erfaringer, der trækkes på, hentes ofte i et tidligere arbejdsliv og løsninger tænkes parallelt med almindelige erhvervsfunktioner. Den politiske praksis formuleres typisk som et samarbejde mellem kolleger. Historien, der fortælles gennem denne diskurs, handler om politikeren, der mest arbejder alene og som gerne vil kunne måle sin indsats på sine resultater. En vigtig del af det politiske arbejde er at skaffe sig gode kontakter, at have en uformel og tæt relation til sit bagland, til andre politikere og udadtil i samfundet. Partiet synes ikke at spille en særlige fremtrædende eller aktiv rolle i det daglige, politikeren står først og fremmest til regnskab for sig selv.

\section{Sammenfatning}

De tre magtdiskurser giver et billede af, hvordan politikere læser det politiske felts vilkår og former forskellige diskursive praksisser i forhold hertil, når det gælder egen karrierevej i politik - diskursive praksisser, der er mere eller mindre i overensstemmelse med den praksisdiskurs, som bruges til at løfte nogle adfærdsnormer og egenskaber positivt frem, andre negativt, og som danner grundlag for inklusions- og eksklusionsprocesser i feltet. Praksisdiskursen løfter samarbejde mellem politikere, fællesskab, fortrolighed og politiske resultater, som forudsætter hårdt arbejde, viden og politisk tæft frem som fænomener, der er skattede og derfor inkluderende i det politiske fællesskab. Høj grad af personlig profilering og manglende konstruktivitet, resultatorientering og aftalebrud bli- ver ekskluderende. At lægge vægt på egen indsats og på netværk uden for politik i det politiske arbejde, som det er tilfældet i kamp-diskursen, må ses som ekskluderende praksisser i forhold til praksisdiskursen i den udstrækning, at dette er udtryk for manglende samarbejde og fællesskab indadtil - en tolkning, der ville placere den diskursive praksis, der udtrykkes i kamp-diskursen, i periferien af det politiske felt, mens partifællesskabsdiskursen ville placere sig centralt i feltet, fordi den rummer flere inkluderende praksisser. Det samme gælder diskursen om den personlige indsats, som også lægger vægt på samarbejde og internt netværk. I det følgende vil jeg præsentere de to kønsdiskurser og herefter diskutere, hvordan feltets kønnede aktører kombinerer magtdiskurser og kønsdiskurser og hvilke handlerum og samspil mellem køn og politik, disse kombinationer afsætter.

\section{Diskurser om køn}

I feltets diskurser indgår to former for italesættelser af kønnets betydning. Den ene fremhæver køn som betydningsløs i den politiske hverdag, og den anden taler om køn som noget, der har afgørende tydning i politik. Begge disse diskurser rummer modificerede underformer, som er mere ambivalente og mindre absolutte i deres udtryk.

\section{Køn har ikke betydning i politik}

Det karakteristiske indhold i denne diskurs er afvisningen af, at køn har betydning i det sociale rum, man udøver sin politiske virksomhed i, det være sig Folketinget, kommunalbestyrelsen, partiet eller andet. Forskelle, der kan give anledning til forskellige betingelser for de to køn, eller problemer, der eventuelt måtte afføde forskelle mellem kønnene, placeres uden for det politiske univers, i samfundet, i familierne eller beskrives som 
betingede af historiske fænomener, der er under afvikling. Udgangspunktet for denne diskurs er opfattelsen af, at der ikke er forskel på mandlige og kvindelige politikere:

...jeg mener ikke, man kan identificere nogle entydige dårlige eller bedre egenskaber hos kvindelige politikere end mandlige (mandlig politiker).

... i hvert fald i en yngre generation af politikere, der udviskes forskellene mere og mere (mandlig politiker).

Køn er et fænomen, der ligger uden for politik - et område, der må håndteres privat af den, der er "berørt" af det:

... jeg mener ikke, at det skal klandres Folketinget, hvis kvinderne er så åndssvage - nu bliver jeg lidt grov - så de har sørget for, at det er dem, der også har ansvaret derhjemme for alting. Når de går ind i sådan et job som det her, ja så kan de godt få nogle problemer, men det kan mændene altså også (kvindelig politiker).

Der eksisterer også en mere modificeret form, hvor grundsynspunktet stadig er, at der ikke er tale om, at den politiske verden som sådan gør forskel på køn, på en måde, der stiller kvinder dårligere, men at de kønsforskelle, der findes, alligevel slår igennem i den politiske verden. Forskellen på denne og den følgende diskurs: at køn har betydning i politik, er, at der her enten ikke drages nogen konsekvenser af disse indsigter med hensyn til deres mulige betydning for de to køns vilkår i politik, eller at konsekvenserne bagatelliseres og diskussionen forskydes:
Nej, men de (betingelserne for de to køn) er forskellige fra, hvis der er børn involveret, så er de forskellige - Ja, så bliver de forskellige også med hensyn til køn, der har kvinderne det sværere (...).Vi har jo haft en del mødre i gruppen, også nybagte mødre, og de har det hårdt, de har det hårdere end nybagte fædre. Men i det hele taget, altså så er der en stor skillelinie mellem dem, der har børn og dem, der ikke har børn (kvindelig politiker).

Køn i politik bliver et ikke-problem - en illegitim diskussion, fordi spørgsmålet om kønnets betydning lægges uden for det politiske felt. Derfor lægges der også afstand til tiltag, der behandler problemet som noget, der handler om politikere og som kan løses blandt politikerne:

Det var meget morsomt, jeg kan huske i de første år i folketingsgruppen at vi, at de yngste kvinder stillede sig op og sagde, nu gad de ikke høre mere på det der ligestillingsbræk (mandlig politiker).

Ved du hvad, vi havde kønskvotering i partiet en kort overgang. Det første sted ... jeg ved ikke om den kom i brug nogle steder, men det første sted den var ved at komme i brug, det var i Rødovre kommunalbestyrelse, men til fordel for mændene, altså de socialdemokratiske mænd, der var simpelthen for mange piger (kvindelig politiker).

De politikere, der udtrykker deres kønsforståelse gennem denne diskurs, håndterer den udfordring, der ligger i, at både arbejdsbetingelserne i politik, ansvarsfor- 
delingen mellem kønnene i familien og de komplekse kønnede vilkår, der viser sig i karriere-forløbene, modsiger denne diskurs' fremhævelse af lige betingelser for de to køn i politik, gennem at fortælle en hårfin balance frem i afgrænsningen mellem politik og den omliggende verden. I diskursen fastholdes forståelsen af, at køn er betydningsløst i den politiske hverdag ved at indsnævre fokus til et begrænset politikfelt - hovedsagligt Folketinget. Diskursen, herunder også dens modificerede udgave, italesætter en opfattelse af en skarp afgrænsning mellem Folketinget og verden udenfor - både resten af samfundet, men også den øvrige del af det politiske system, og dermed lægges også afstand til forsøg på at ændre uligheder i det politiske system.

\section{Køn har betydning i politik}

I den anden overordnede diskurs om køn og politik begrebsliggøres politik gennem kønnet - politik er kønnet: i sin magtstruktur, i sine arbejdsformer, i sine politiske udtryk og i sin effekt. De forskelle, der fremhæves mellem kønnene, spiller en rolle i det politiske felt. De tages som udtryk for politikkens kønnede univers og tolkes ind i politik som et kønnet magtfelt, hvor det er mændene, der sidder på magten. Udgangspunktet for denne diskurs er det modsatte af den foregående og består i, at der er forskelle på mandlige og kvindelige politikere.

Altså jeg synes gennemgående, at kvinder i politik har været meget mindre teknokratiske end, jeg synes, mine mandlige kolleger har været.. (kvindelig politiker).

..nu er jeg meget emotionel, altså os kvinder - der er også mænd, der er emotionelle, men nu er jeg meget emotionel og det har altid været et problem, (...) Jeg tror vi er meget forskellige - kvinder nyder jo heller ikke at slås...(kvindelig politiker).

Selve magtstrukturen i politik anskues kønnet. Politik struktureres efter mændenes måde at arbejde på, den politiske kultur opfattes som mandekultur, hvor kvindernes indtog i politik ses som en provokation. Kønsforskelle og kønnede eksistensbetingelser og vilkår har indflydelse i den politiske verden, men denne indflydelse kan også fortælles frem uden, at der kobles til forestillingen om en mandsdomineret politisk verden.

...men jeg tror, det er, det er - fuldstændigt som vi kender det fra andre af livets forhold - at indtil man har en fuldstændig ligestilling, så er det jo sådan, at kvinder vil være udsat for større krav og større kritik for at gøre det samme som mænd i den samme situation, men det er ikke noget specielt for politik (mandlig politiker).

Altså - det er stærkt overdrevet, den problemstilling, fordi når man sidder på den position, som jeg gør, så er det jo fuldstændig ligegyldigt om man er en kvinde eller en mand. Det forandrer jo ingenting, om jeg er kvinde eller mand. Mine måder at gøre tingene på, mine beslutninger og valg og det ene og det andet, det kan selvfølgelig influeres af, at jeg er kvinde. Men jeg mener, min position, autoritet, magt, hvad du vil vælge at kalde det, internt i regeringen har ikke noget at gøre med mit køn. Samarbejdet i regeringen er anderledes, fordi jeg sidder på den post, som jeg sidder på, vil jeg vove at påstå. Altså det er anderledes, end hvis det havde været en mand, der 
havde siddet på min post. Fordi jeg er opmærksom på nogen andre ting - tror jeg (kvindelig politiker).

Som det fremgår af dette citat rummer denne diskurs også italesættelser af kønnets betydning, som er ambivalente hvor den konkrete brug af diskursen lægger afstand til en opfattelse af, at de kønnede betydninger kobles til mandsdominans.

Den første diskurs fortæller historien om køn og politik som en historie, hvor mandlige og kvindelige politikere ikke er forskellige, hvor de to køn ikke behandles forskelligt i politik, hvor den samfundsmæssige kønsarbejdsdeling ikke behøver at slå igennem i politik og hvor arbejdsmåderne i politik ikke er kønnede. Historien om kønnet $i$ den anden diskurs fremhæver, at kvindelige og mandlige politikere er forskellige, at mænd og kvinder behandles forskelligt i politik, at der er forskel på kvindelige og mandlige politikeres arbejdsmåder og at samfundsmæssige kønsforskelle også er virksomme i politik. Men de to diskurser rummer også en række fællestræk, som kort fortalt taler om eksistensen af kønskonventioner med kønsstereotypt indhold, om omverdenens kønsbestemte forventninger og pressens ulige behandling af de to køn. Begge gør det desuden til en del af deres fortælling, at køn har betydning for arbejdsformerne både på den måde, at kvindernes indtog i politik har betydet en mærkbar ændring i tilrettelæggelsen af det politiske arbejde - færre aftenmøder, større respekt for børnefamiliernes behov og på den måde, at der har været større fokus på familiepolitik efter, at andelen af kvinder i politik er steget.

\section{Det politiske felt og dets kønnede aktører}

Det politiske felts magt- og kønsdiskurser er båret af og aktiveres gennem køn- nede aktører - konkrete kvinder og mænd. Disse diskurser er, sammen med andre diskursive praksisser, eksempelvis selve politikområdet, med til at afstikke de handlerum, der er tilgængelige (men også ikke-tilgængelige) for de kønnede aktører. Der kan i disse koblinger spores kønnede mønstre, der kan tjene som eksempler på, hvordan diskurser om at komme til magten og kønsdiskurser - politik og køn - gensidigt konstituerer hinanden. Det vil jeg give nogle bud på i det følgende. De tre magtdiskurser er alle "befolkede $^{\prime \prime}$ med både mandlige og kvindelige politikere, lige som det både er mænd og kvinder, der gør brug af de to kønsdiskurser. Men mænd og kvinder kobler de to diskurser forskelligt.

\section{Kampdiskursens kønnede aktører - kvinder} Inden for kamp-diskursen er det samtlige kvinder, som har gjort diskursen om køn, som noget der har betydning i politik, til deres egen, og for de fleste er kampdiskursen og denne kønsdiskurs uløseligt forbundne. Det er netop deres køn, der betinger kampen - at komme til magten i politik som kvinde er en vedvarende kamp.

Og det har måske været overraskende for mig, at kampen var slem, da vi var der i 20'erne og skulle have uddannelsen frem til pladserne, at den var slem undervejs til ordførerskaberne og udvalgsformandsposter og ministerposter og den er der stadigvæk. Det er nok kommet lidt bag på mig. (...) Jeg troede måske på et tidspunkt, at det hørte op, så var vi bare lige. Men nej, det er ikke hørt op, det er nærmest blevet værre (kvindelig politiker).

Det er også en kamp, der er tæt knyttet til et generationsoprør i 60'erne og 70'erne, 
hvor kampen mod mændenes dominans var en del af et bredere autoritetsopgør, der gjaldt såvel politikforståelsen - opfattelsen af hvad der var politik og ikke politik - hvem der kunne "befolke" politikken, måden at organisere det politiske arbejde på - samspillet mellem politiske bevægelser og partipolitikken - og ikke mindst de partipolitiske arbejdsformer:

Vi var jo en hel kaffeklub, der kom ind (...) og vi fik jo hurtigt fordelt opgaverne strategisk (...) og så støttede vi hinanden i vores kaffeklub, med at bakke hinanden op. For de havde jo den der moppekultur - der var jo i hvert fald ingen, der skulle tro, at de var noget, og slet ikke de unge. De kunne godt sidde de første år og holde kæft, men vi var ikke skruet sådan sammen. Vi kom jo fra universiteter, seminarier og læreranstalter og var meget kollektive. Vi havde jo siddet i gruppearbejde hele tiden, og det troede vi jo, vi kunne fortsætte med herinde. Men sådan var det jo ikke lige, selv om det formelt hedder, at vi har en gruppe. Det var individuelt karriereræs ... det var ikke bare karriere, men et ræs for at få sine ideer igennem. Så det er en magtkamp lige fra begyndelsen (kvindelig politiker).

Kvinderne ser sig selv som typiske repræsentanter for deres generation af kvinder, som i hidtidigt uset stort antal gik ind på uddannelserne og ud på arbejdsmarkedet, og de sympatiserede med og så sig for nogens vedkommende som en del af den nye kvindebevægelse. Den kvindepolitiske dimension var et vigtigt element i deres politiske mobilisering, en dimension, der ofte blev forstærket i mødet med den politiske verden, og for nogle blev kvindepolitikken en del af deres politiske platform. De så sig som en del af en generation af kvinder, der havde sat sig for at bryde med et mandligt definitionsmonopol - i samfundet og i politikken - og som en del af en generation, der ville bekæmpe støvede og traditionsbundne organisationsformer og hierarkier - i partiorganisationerne og i samfundet. Strategien var at tage kampen op på alle fronter: lige fra overvejelser over udseendes og påklædningens betydning for at blive taget alvorligt, over erobring af ordet og taletiden, til kamp om en plads i finansudvalget og i de øvrige vigtige udvalg og udvalgsformandsposter.

\section{...Man lærer den jo, jeg lærer at gerere mig i den [mandekulturen]. Det betyder jo ikke at acceptere den, men det betyder bare, at den står mig meget klart, og jeg kan operere i den, (...) på den måde, at jeg prøver at være mindst lige så udfarende og bede om ordet lige så tit, som mænd gør, bare af reto- riske grunde (kvindelig politiker).}

Strategien var at lære feltets fremgangsmåder, kneb og finesser og bruge dem til egne formål. Det indebar målbevidst arbejde for at bringe sig selv og hinanden i position til at erobre de centrale poster gennem alliancer, kaffeklubber og kvindelige netværk og gennem at hente støtte, inspiration og samarbejdspartnere $\mathrm{i}$ samfundet ved at knytte alliancer med politiske bevægelser og bredere netværk uden for politik.

Det handlerum, der afstikkes i denne kombination af diskursive praksisser, knytter køn og politik sammen i en kamp, der også er personlig. Den sociale indignation og ønsket om et retfærdigt samfund med en mere ligelig fordeling af goderne, der formuleres som politiske mål, får en personlig dimension både i bekæmpelse af kønsbestemte uligheder i 
den politiske repræsentation og i kampen for forbedring af kvindernes stilling i samfundet. Køn og politik bliver her gensidigt konstituerende gennem en eksplicit sammenkobling - de diskursive praksisser, knyttet til hhv. køn og politik, låner hinanden identitet og er med til at udforme hinandens handlerum.

\section{Kampdiskursens kønnede aktører - mænd}

Det gælder ikke, når den politiske aktør er mand. Her kombineres kampdiskursen med en opfattelse af, at køn ikke har betydning i politik. Kampdiskursen gælder her også erobring af positioner med henblik på fornyelse og nytænkning, men det gælder i mindre grad et organisatorisk opgør - vægten ligger på fornyelse af politikken, og ulighederne opfattes ikke som kønsbestemte:

... jeg tror, jeg tilhører en anden generation (...) Altså jeg har forstået det på den måde, at de unge kvinder, der var med, de mente, at de skulle nok selv, og de kunne sagtens klare sig i konkurrencen med mænd. Så jeg har aldrig syntes, at jeg har haft behov for at gøre noget specielt for kvinderne. Jeg har haft behov for at gøre noget for mennesker, for at yde en indsats for de mennesker, som ikke er født med en guldklump i røven (mandlig politiker).

Som han selv siger, tilhører han den næste generation, (efter 70'ernes kvindepolitisk aktive generation) og her hænger køn og politik ikke sammen, hverken i den forstand at kønsmæssig lige repræsentation blandt politikere opfattes som et problem - kvinder har ofte bedre muligheder for at blive valgt end mænd - eller i den forstand, at der skal være kvinder i politik. Det vigtige er, at ligestillingen sikres samfundsmæssigt:
Der har altid været kvinder i politik, men der har været for få. Ja, det betyder jo.. jamen jeg tror, man skal måske sige det på en anden måde, jeg tror, det betyder noget, at der er lige så mange kvinder på arbejdsmarkedet, som der er mænd. Så det med, at man skal have kvinder i politik, er også lidt for snæver en definition, som om politik kun er alt det der foregår på Christiansborg. Politik ...Vi er jo politikere alle sammen... (mandlig politiker).

Hvis man her skulle tale om et handlerum udstukket af koblingen af de to diskurser handler det snarere om, at køn kommer i vejen, når det handler om politik - køn er politik uvedkommende. Spørgsmålet om køn er en forældet problematik, om end den stadig har samfundsmæssig betydning. Eksempelvis er mænd også blevet et køn, der påvirkes af de samfundsmæssige ændringer i kønsrelationerne:

Vi har svært ved, det er svært at være mand i dag, ja, det tror jeg (...) det [at rollerne er mindre faste] gør det sværere, det gør det mere spændende, men jeg tror også, det gør det sværere... (mandlig politiker).

Spørgsmålet om køn håndteres med ambivalens: på den ene side tillægges det ikke betydning (i politik). På den anden side tillægges de to køn forskelle - eksempelvis argumenteres der med, at kvinder prioriterer anderledes end mænd - også når det gælder politisk engagement.

I dette handlingsrum ser det ud til, at ambivalensen overvindes ved at ekskludere køn fra politik. 
Partifxllesskabets kønnede aktører - kvinder

De kønnede mønstre, der kan identificeres i koblingen mellem magtdiskurs og kønsdiskurs inden for partifællesskabet, er helt anderledes end ovenstående. For de kvindeligt kønnede aktører i dette praksisfelt har køn ikke betydning i politik, og det handler ikke om generationer - begge kvindegenerationer er repræsenteret. Det er en holdning, der også begrundes personligt:

\begin{abstract}
Jamen altså ved du hvad, jeg -- har jo i virkeligheden aldrig haft sans for det problem, og det hænger jo sammen med, at jeg er vokset op i en mandsverden, (...) jeg kom til at sige til en journalist ved en kvindekonference „nej jeg har aldrig været, og jeg bliver aldrig nogen sinde medlem af en kvindeorganisation" , og jeg fik så mange bank, da jeg kom hjem. Men altså jeg synes ..., for mig ville det være ..., jeg synes simpelthen ikke det ville være rimeligt, altså det ville være uægte at gå ind i en kvindeorganisation, eller kvindeinitiativ, eller kvindekongres (kvindelig politiker).
\end{abstract}

Denne holdning udelukker ikke en forståelse for, at der kan eksistere diskrimination, og at betingelserne for de to køn kan være forskellige - men det gælder som ovenfor nævnt ikke det konkrete politiske rum - men nok verden uden for politik. Alligevel udelukker den heller ikke en opmærksomhed på, at der ikke må foregå en kønsskæv udvikling:

Nej altså, jeg kan sige, vi havde en periode lidt .., og det er såmænd ikke så vanvittig mange år siden, hvor vi sagde „hov hov hov, nu har vi fået en tendens ..", jeg kan huske blandt andet det var skatte- udvalget, der havde vi simpelthen ikke nogen kvinder nej, og så sagde vi, jamen det vil vi ikke acceptere, vi vil have kvinder i alle udvalg (kvindelig politiker).

Den modsætning, der kommer frem her, kan måske forstås i lyset af, at der her tales op imod en diskurs, der handler om, at kvinder i politik har det svært - en diskurs, som har præget den kvindepolitiske diskussion både blandt kvindelige politikere og kvindeforskere op gennem halvfjerdserne og firserne, og som denne diskurs kvindekønnede aktører føler behov for at lægge afstand til:

Det der martyrium, nogle gerne vil give også til topkvinder, som de dog alle sammen må siges at være, det er jeg ikke enig i (kvindelig politiker).

Partifællesskabets kønnede aktører - mænd Blandt mændene er begge kønsdiskurser repræsenteret, og her er de generationsspecifikke - de yngre mener ikke, at køn har betydning, mens de ældre mener, at køn har betydning om end i en langt mere modificeret form end den, der kommer frem hos kamp-diskursens kvindelige politikere. Der lægges eksplicit afstand til kamp-diskursens kvindelige aktørers opfattelse af de kønnede betingelser i politik blandt den yngre generation af mandlige aktører:

Kvinde kampen har været ført tidligere på, at man var konkurrenter også mellem kønnene, (...) Og de kvinder, der ligesom var optrænede $i$, at kampen, ligestillingskampen gik mod kønnet og ikke i en alliance - det er der måske blevet mere om nu tror jeg - (...) - altså vi har jo gået efter nærmest ligelig kvotering af kvinder og mænd. Og 
så sidder man, så kommer man jo nemt $i$ en situation, hvor man siger til hver post, der skal der være en kvalificeret kvinde og en kvalificeret mand, og derfor finder man ud af "hvem er min .., hvem er min største modstander, det må være den kvalificerede kvinde til dette her job". Det, tror jeg nok, er en del af problemet ved ligestillingskampen, at den er gået som konfrontation og ikke i en fælles alliance og forståelse af, at vi skulle prøve at finde fælles styrker og udnytte forskelligheden mellem mænd og kvinder, drenge og piger (mandlig politiker).

På den ene side underkendes magtaspektet i 70'ernes kønskamp, og der lægges afstand til ligestillingskampen og kønskvoteringen, fordi den befordrer konkurrence, hvor der skulle være alliance. På den anden side konstateres det, at relationerne mellem kønnene ikke har rykket sig meget på trods af ligestillingskampen, og at forskellene ønskes fastholdt:

Jeg tror desværre, jeg må konstatere, at det stadigvæk er sådan, at mænd søger mænd og kvinder søger kvinder altså i personrelaterede forhold (...) jeg synes stadigvæk, at jeg kan opleve,(...) at det er søster- og broderskab, der går igen i det politiske (...) det er min egen oplevelse, jeg synes ikke det har flyttet sig så meget på trods af ligestillingsdebatten (..) det moderne broderskab er, er på vej ind igen. Altså kvinder kan også godt lide det, jeg tror, kvinder kan godt lide at øh mænd har noget sammen, øh, ligesom kvinderne skal have noget sammen, jeg tror den der med spændingen imellem kønnene, den må, den må for guds skyld ikke forsvinde og den har også noget at gøre med, at vi også har vores egne verdner, vi skal have vores egne små rum og så skal vi i øvrigt primært kunne lave noget sammen, og bruge hinandens styrker (mandlig politiker).

Ambivalensen balanceres ved hjælp af visionen om en spænding mellem kønnene, som vil eliminere konkurrencen og åbne for ligeværdige alliancer mellem kønnenes forskellige verdener - en vision, der har som sin forudsætning, at der ikke eksisterer kønnede betingelser for deltagelse i politik, og at køn på denne måde ikke har betydning i politik. Handlingsrummet i denne kobling af magtdiskurs og kønsdiskurs kunne beskrives sådan: Kønskampen er overstået, de to køn står lige, og nu skal der samarbejdes ud fra de forskellige kønnede positioner. Den italesættelse af køn, som udtrykkes her, adskiller kønnede positioner fra kønnede betingelser. Der eksisterer kønnede positioner, men ingen kønnede betingelser - opfattelsen bygger således på en åbenlys modsætning, som ikke adresseres.

De mandlige aktører, der udtrykker sig gennem partifællesskabsdiskursen og som mener, at køn har betydning i politik, har et pragmatisk og praktisk forhold til politikkens kønnede uligheder, der enten udtrykkes som en distanceret afventen: Udviklingen bevæger sig i mod en udligning af forskellene, eller forfægter en opfattelse af, at aktiv indgriben er nødvendig:

Der er for mange, der har det her med: "Åh, det gider vi ikke høre på". Altså, der er også mange kvinder, der siger: "det gider vi ikke høre på". Men hvis man ikke gør noget aktivt for at ændre de 
der forhold, så sker der ingenting (mandlig politiker).

Der tales her fra positioner, der ikke trues af konkurrence fra kvinderne, enten fordi der tales fra en absolut ledelses position, eller fordi man har sit politiske område for sig selv:

\begin{abstract}
Altså fraværet af kvindelige politikere på mit felt, gør jo at jeg kan sådan set ikke rigtigt komme i tanke om, at jeg på noget tidspunkt har været i direkte konkurrence med en kvinde..(...) altså jeg, jeg har personligt ikke oplevet forsøg på at skubbe sig ind [latter], lige der, hvor jeg har været, det har jeg ikke (mandlig politiker).
\end{abstract}

Også her rummer magtdiskursen flere bud på det politiske handlerum - eet som bruges af de kvindelige aktører sammen med de yngre mandlige aktører og hvis grundstruktur er, at kønskampen ikke hører hjemme i politik, enten fordi kønsforskellene ikke er relevante i det politiske handlerum - forskellene ligger udenfor - eller fordi forskellene skal udnyttes til samarbejde - og eet som udtrykkes af den "ældre" generation af mandlige politiske aktører, og som ligger på linie med kampdiskursens kvinder i opfattelsen af, at der er behov for aktivt at sikre kønnene lige betingelser.

\section{Den personlige indsats' \\ kønnede aktører - kvinder}

De kønnede mønstre, der kommer frem i koblingen mellem diskursen om den personlige indsats og kønsdiskurserne er karakteristiske på den måde, at distinktionen mellem de kønnede aktører ikke går på, om køn tillægges betydning i politik eller ikke - køn har betydning i politik - men på hvordan denne betydning forstås. Udgangspunktet er, at der er forskel på de to køn, og disse forskelle defineres forskelligt $\mathrm{i}$ forhold til det politiske felt. De kvindelige aktører understreger forskellenes betydning for den politiske aktivitets kerneområder. Det handler om, at de træk, der tillægges de kvindelige politiske aktører, bidrager til at befordre centrale politiske processer:

Der er meget med, man snakker lidt privat, på tværs af partierne og det gør man også internt, men det kan de mandlige politikere altså også gøre, men jeg ved, at de gør det ikke i så høj grad, som vi gør det, vi bruger jo ofte hinanden, hvis der skal laves nogle tillidsskabende foranstaltninger på tværs af partierne, og så er det klart, dem af os, der har de bedste personlige relationer, vi bliver så bedt om at prøve at undersøge, hvordan står forholdene i det parti, og det er klart, så bruger vi jo vores personlige relationer, dem har vi meget glæde af (kvindelig politiker).

De formulerede forskelle bruges aktivt der trækkes i trådene bag kulisserne, og der er ofte tale om muldvarpearbejde, som skaber muligheder, rydder misforståelser af vejen og støber kugler, som er vigtige i den politiske proces:

Ja, f.eks. er jeg meget opmærksom på, hvordan de andre ministre har det.(...) jeg kan jo mærke den tillid, som andre ministre har til mig, og som jo også kommer til udtryk ved, at de ringer til mig og spørger mig om noget, og beder om et råd, eller gør mig opmærksom på noget, om jeg ikke kunne hjælpe dem i den og den situation (kvindelig politiker). 
Den personlige indsats

kønnede aktører - mænd

I modsætning til ovenstående formulerer de mandlige aktører forskellene på en måde, der placerer de kvindelige særtræk i periferien af det politiske felt:

\begin{abstract}
Altså de ministre, der siger at nu er klokken 4, nu går jeg hjem, det har jeg aldrig kunnet forstå.., halv fire endda har jeg iagttaget - jeg skal ikke nævne hende ved navn. Men de kommer altså også typisk til kort hver gang man går lidt ind under overfladen, fordi der er ingen erstatning for forberedelse (...) men hun prioriterer børnene højere, og det kan man sådan set godt forstå, men det koster altså i form af, at så sidder man ikke så solidt ved forhandlingsbordet (mandlig politiker).
\end{abstract}

De to køn siges at komplementere hinanden i politik, men på en sådan måde at de mandlige aktører tilskrives adfærd og egenskaber, der karakteriserer politikkens kerneområder: beslutsomhed, initiativrig, dagsordensættende og hårdtarbejdende, mens de kvindelige aktører tales frem ved hjælp af følelseskategorier: omsorgsfulde, samvittighedsfulde, ansvarsfulde, tøvende, betænksomme og ordentlige. Disse forskelle tilskrives dog ikke den store betydning i politik, fordi de grundlæggende ikke ændrer måden at lave politik på:

Nej det synes jeg ikke, og det har altid været sådan, at når piger har været i politik i et stykke tid og går ind i de mandlige rollefag, så er det meget svært at skelne deres fremtræden i forhold til mændene (mandlig politiker).

De kvindelige aktører er nyankomne og anderledes, og selv om de lærer det, kan de alligevel på det personlige plan opleves som de fremmede:

Det er nok nemmere at føle tillid til en aftale, du indgår med en mandlig politiker end en kvindelig politiker. Nu spørger $\mathrm{du}$, men altså når jeg tænker over det, så føler jeg, det er nemmere, jeg føler, jeg per automatik nok kan stole lidt mere - hvis jeg sidder og siger „ok så gør vi sådan og sådan, og det er så en aftale". Der ville jeg ikke have den samme sikkerhed, hvis jeg skulle lave den samme aftale med, altså nu helt generelt, en kvindelig politiker, det vil jeg ikke føle den samme sikkerhed ved (mandlig politiker).

Det handlerum, der tales frem her, har to sider. På den ene side lægger det op til, at de kvindelige aktører benytter særlig tilgange til indflydelse på den politiske proces, og på den anden side bliver de kvindelige aktører kun fuldgyldige politiske aktører gennem at agere som mændene. Eller man kunne tale om to kønnede handlerum, eet hvor kvindelige aktører definerer kvinde-kønnede særtræk som centrale og befordrende for den politiske proces, og eet hvor mandlige aktører definerer kvindekønnede særtræk som et perifert fænomen, der først og fremmest opnår positiv betydning ved at blive elimineret.

\section{Konklusion}

Køn og politik spiller sammen på mangfoldige måder. Der kan ikke lokaliseres entydige mønstre båret af enten kønnede diskurser eller magtpositionerede aktører. Som det er fremgået af denne analyse, bruges kønskategorien til at løfte visse aktører frem - og ikke andre - $\mathrm{i}$ visse sammenhænge og ikke i andre. Den bruges 
til at understrege betydningen af visse praksisformer på bekostning af andre og til at tillægge adfærdsformer, egenskaber og forventninger kønnede betydninger inden for den variation af kontekster, der udtrykkes gennem magtdiskurserne i det politiske felt. Analysen viser, at det er i, koblingen mellem køn og politik, at der kan spores en forskel i måden at agere på mellem kønnene og ikke så meget $\mathrm{i}$ hvordan de to køn gør politik eller hvordan de italesætter køn. De kønnede mønstre i denne kobling peger på, at der trods mangfoldigheden i samspillet mellem køn og politik ligger kønnede anvisninger på, hvordan henholdsvis kvindelige og mandlige politikere kan bevæge sig i feltet.

De kønnede mønstre i brugen af kønskategorien, der viser sig gennem koblingen mellem magtdiskurs og kønsdiskurs, kan yderligere belyses ved at se på relationen mellem magtdiskurserne og praksisdiskursen. Det er eksempelvis karakteristisk, at kampdiskursen på en række punkter fremhæver andre praksisprioriteringer end de, som formuleres som centrale i feltets praksiskodeks. Som vist gælder dette både diskursens understregning af vigtigheden af egen indsats og samarbejdet i netværk uden for politik. Det er især de kvindelige aktører, der pointerer betydningen af de politik-eksterne netværk. Samtidigt karakteriseres nogle af kampdiskursens kvindelige politikere af andre politikere ved, at de profilerer sig selv og ikke kan skabe resultater. Begge disse karakteristikker er ifølge feltets praksiskodeks ekskluderende. Endeligt siges det om nogle af de kvindelige aktører, at de opfører sig som mænd $\mathrm{i}$ betydningen fører sig magtfuldt frem en karakteristik, som både nedvurderer dem som kvinder, og som søger at underminere den kønsdiskurs - hvis omdrejningspunkt er mandsdominansen - som de kvindelige aktører i kampdiskursen står for - ved at hævde, at kvinderne selv opfører sig som mænd. Kombinationen af kampdiskursens egne prioriteringer, de karakteristikker, dens kvindelige aktører behæftes med, og de kvindelige aktørers egne fremhævelser af den snævre sammenhæng mellem køn og politik - i et univers, der i overvejende grad lægger afstand til en sådan sammenhæng - ser ud til at placere kampdiskursen relativt perifert i feltet sammenlignet med de to andre diskurser.

Både partifællesskabet og den personlige indsats er som magtdiskurser placeret langt mere centralt i forhold til feltets praksiskodeks. Begge lægger vægt på det resultatsøgende samarbejde med andre politikere. Når der forekommer ekskluderende karakteristikker, som f.eks. dovenskab, kobles disse med inkluderende evner, som eksempelvis politisk tæft eller samarbejdsbefordrende praksisser - som at give andre æren for de opnåede resultater - og på denne måde neutraliseres de ellers ekskluderende praksisformer inden for diskurserne.

Det er tillige karakteristisk for diskursen om partifællesskabet, at den er kønnet på den måde, at det er de mandlige politikere, der udtrykker begejstringen for fællesskabet, og som beskriver de kammeratlige relationer, den personlige gensidighed, som binder det sammen, og de fordele, der er forbundet med det. Det fremstår derfor i højere grad som et mandligt fællesskab, som kvinderne deltager $i$, end som et fællesskab, der omslutter begge køn på samme måde. Det betyder, at det først og fremmest er mænd, der løftes frem i denne diskurs og gøres synlige og betydningsbærende, og selv om dette i højere grad gælder mændenes måde at bruge diskursen på, så brydes dette ikke i særlig høj grad af kvinderne. De løfter hverken mænd eller kvinder specielt frem. Man kan sige, at de kommer til at bekræfte deres deltagelse i fællesskabet 
ved - på linie med fællesskabets yngre mænd - at tage afstand fra opfattelsen af, at køn har betydning i politik. Hermed lægger de også afstand til kampdiskursens kvinder - en gestus, der tillige kan ses som en bekræftelse på, at de er en del af fællesskabet.

En enighed på dette punkt mellem mandlige og kvindelige aktører kan ikke spores i de andre to magtdiskurser, som heller ikke på samme måde rummer et fællesskab som en central dimension. Kampdiskursens kvindelige aktører står alene med deres opfattelse af politik som kønnet hele vejen igennem, og de mandlige og kvindelige aktører, der bruger den personlige indsats' diskurs, ser helt forskelligt på, hvilken betydning køn har i politik.

Dette brogede billede af handlerum og forhandlingsrum, som kommer til syne i disse magt- og kønsdiskurser, viser, at køn som ordens- og meningsskabende kategori indgår med meget forskellige stemmer i mange forskellige processer i det politiske felt, og netop dette brogede billede giver mange forskelligartede muligheder for forhandlinger og for fleksible tolkninger af både praksisser og aktører. Selv om det ser ud til, at der findes kønnede mønstre for håndtering af det fleksible, så vil de kønnede mønstre formentlig ændres hen ad vejen, afhængigt af hvordan de anvendes af konkrete aktører i feltet.

\section{Noter}

1. Denne forståelseshorisont henter mht. magtforståelsen inspiration hos Foucault (Gordon 1980, Rabinow 1984) og med hensyn til kønsforståelsen hos poststrukturalistiske kønsforskere som Butler $(1993,95)$, Davies (2000), Søndergaard (1996).

2. Denne interviewundersøgelse er den kvalitative del af det danske bidrag til A Comparative Leadership Study (se Vianello og Moore 2000, Højgaard 1998, 2001, 2002, Højgaard \& Esseveld 2000), som er en sur- veyundersøgelse af mænd og kvinder i toppositioner inden for erhvervsliv, politik og offentlig administration gennemført i 27 lande. Interviewpersonerne omfatter medlemmer af regeringen, folketingsmedlemmer, der samtidig sidder på centrale positioner som udvalgsformænd for vigtige udvalg, partiledere, ordførere og borgmestre for de store byer og amter. Interviewene blev foretaget i sidste halvdel af 1990'erne. De interviewede politikere, hvis citater er medtaget her, har haft lejlighed til at kommentere de anvendte citater og artiklen som helhed. Selv om ikke alle har reageret, har jeg fået værdifulde kommentarer fra flere politikere. Det vil jeg gerne takke for. Jeg vil også gerne takke samtlige interviewede politikere for deres interesserede imødekommenhed og for de spændende samtaler, som interviewene udviklede sig til.

3. Disse tre er ikke udtømmende for materialet, men de repræsenterer de tre mest relevante for nærværende problemstilling. Der kan identificeres en fjerde diskurs i materialet, traditionen - som det bliver for omfattende at inddrage her.

4. Magtdiskurs skal her ikke forstås som teoretisk begreb, men som et hverdagssprogligt udtryk.

\section{Litteratur}

Butler, Judith 1993: Bodies that matter. On the discursive limits of 'sex'. London / New York. Routledge.

Butler, Judith 1995: "Contingent Foundations". L. Nicholson (ed.): Feminist Contensions. A Philosophical Exchange. New York. Routledge, s. 35-59.

Bergqvist, Christina 1999: Likestilte demokratier? : kjønn og politikk $i$ Norden. Oslo: Universitetsforlaget

Davies, B. \& Rom Harré, R. 1990: "Positioning: The Discursive Production of Selves". Journal for the Theory of Social Behaviour, 20 (1).

Eduards, M. 1998: Politik och kön - en historia om skillnader och makt. Statsvidenskabeliga Institutionen. Stockholms Universitet. 
Gordon, Colin (eds.) 1980: Power and Knowledge. Selected interviews and other writings 1972-1977. New York: Harvester.

Haavio-Mannila, E. (red.) 1983: Unfinished Democracy - Women in Nordic Politics. Oxford. Pergamon Press.

Heede, Dag 1992: Det Tomme Menneske. København: Museum Tusculanums Forlag.

Højgaard, Lis 1998: Kvinder og mænd $i$ dansk toppolitik. Institut for Statskundskab. Ap 1998/3.

Højgaard, Lis \& Johanna Esseveld 2000: "The social Construction of Gender". I Vianelleo \& Moore (eds.): Gendering Elites. London. MacMillan Press LTD. 233-247.

Højgaard, Lis 2002: "Tracing Differentiation in Gendered Leadership". I Gender work and Organization, 9 (1). (under udgivelse)

Højgaard, Lis 2001: "Magtens køn. Kønnede betingelser for deltagelse i magteliten". I Anette Borchhorst (red.): Kønsmagt under forandring: Feministiske forståelser af køn, magt og demokrati.. København. Hans Reizel. (under udgivelse)

Lovenduski, J. \& Pippa Norris 1993: Gender and Party Politics. London: Sage.
Paper til Årskonferencen: Between the no longer and the not yet. Arskonference $i$ Foreningen for kvinde- og Kønsforskning. 14.-15. april 2000. Paper: Roskilde Universitetscenter.

Rabinow, Paul 1984: The Foucault Reader. London: Penquin Books.

Raum, Nina C. 1995: Kjønn og politik. Oslo. Tano.

Skjeie, H. 1992: Den politiske betydningen af kjønn. En studie af Norsk toppolitik. Institut for Samfundsforskning. Rapport 92:11. Oslo.

Skjeie, H. 1995: "Politisk Lederskab: Idealer og vrengebilder". I Raum red s. 194-214.

Søndergaard, Dorte Marie 1996: Tegnet på Kroppen. Køn: koder og konstruktioner blandt unge voksne i Akademia. København: Museum Tusculanums Forlag.

Søndergaard, Dorte Marie 2000: Akademiske magtformer og deres kønnede befolkning. København: Tusculanums Forlag.

Vianello, M. \& G. Moore 2000: Gendering Elites. London: Macmillan Press.

Weedon, C. 1987: Feminist practice and poststructuralist theory. Oxford: Basil Blackwell.

West, C \& D.H. Zimmerman 1987: “Doing Gender". I Gender and Society 1(2):125151. 